\title{
Oxidation Behavior and Cracking Susceptibility of Ni-Cr Alloys in Dry Steam and Inert Gas under Extremely-Low Oxygen Partial Pressure*
}

\author{
Hiroshi ABE**, Yasuhiro KENMOKU**, Takayuki ENDO**, \\ Takamichi MIYAZAKI** and Yutaka WATANABE** \\ ${ }^{* *}$ Graduate School of Engineering, Tohoku University \\ 6-6-01-2, Aoba, Aramaki, Aoba-ku, Sendai 980-8579, Japan \\ E-mail:hiroshi.abe@qse.tohoku.ac.jp
}

\begin{abstract}
In order to investigate oxidation behavior and cracking susceptibility of the $\mathrm{Ni}-\mathrm{Cr}$ alloys under extremely-low oxygen partial pressure, three $\mathrm{Ni}-\mathrm{Cr}$ alloys $(\mathrm{Ni}-14 \mathrm{Cr}$, $\mathrm{Ni}-22 \mathrm{Cr}$ and $\mathrm{Ni}-30 \mathrm{Cr}$ ) were used as plate specimen and reverse U-bend specimen for oxidation experiments for 750 hours at $400{ }^{\circ} \mathrm{C}$ in two kinds of gas system (inert gas and dry steam) under various oxygen potential ( $\mathrm{Ni}$ stable, $\mathrm{Ni} / \mathrm{NiO}$ equilibrium and $\mathrm{NiO}$ stable). The $\mathrm{Ni}-\mathrm{Cr}$ alloys cracked along grain boundary both in inert gas system (with trace $\mathrm{O}_{2}$, without $\mathrm{H}_{2} \mathrm{O}$ ) and in hydrogenated steam. In the inert gas system, the cracking susceptibility was confirmed in near $\mathrm{NiO}$ stable condition. On the other hand, no crack was found in near Ni stable condition. In the dry steam system, the cracking susceptibility was confirmed in near $\mathrm{Ni} / \mathrm{NiO}$ equilibrium. In contrast, no crack was found in near $\mathrm{NiO}$ stable condition. The cracking susceptibility was confirmed in near $\mathrm{Ni} / \mathrm{NiO}$ equilibrium in hydrogenated steam as contrasted with higher oxygen potential in inert gas system. This result shows that potential range for the cracking susceptibility seemed to be different between the two kinds of gas system. Cracking severity was highest for Ni-14Cr and lowest for $\mathrm{Ni}-30 \mathrm{Cr}$ both in inert gas and steam; however, even Ni-30Cr was not immune to intergranular cracking in steam near $\mathrm{Ni} / \mathrm{NiO}$ equilibrium.
\end{abstract}

Key words: Ni-Cr Alloy, Grain Boundary, Oxygen Partial Pressure, Superheated Steam, Oxidation

\section{Introduction}

Stress corrosion cracking (SCC) of structural alloys in a light-water reactor is one of the most considerable issues for the safe plant management. Since SCC thought to be a complex phenomenon which relates material, environment and mechanics factors, the mechanism of SCC is not fully understood. In the recent findings, the inward oxidation with selective oxidation of specific alloying elements was observed near the crack tip of L-grade stainless steels in boiling water reactor (BWR) environment and of Ni-base alloys in pressurized water reactor (PWR) primary water environment by using analytical transmission electron microscope (ATEM) ${ }^{(1,2)}$, and selective internal oxidation (SIO) is proposed as a root mechanism of intergranular stress corrosion cracking (IGSCC) of alloy600 in a primary water environment ${ }^{(3)}$. Hydrogenated steam is widely accepted in cracking tests as a substitute environment for a primary water environment ${ }^{(3-6)}$. However, cracking susceptibility of $\mathrm{Ni}-\mathrm{Cr}$ alloys in the simple oxidation system (inert gas with trace oxygen) and particular correlation between cracking susceptibility and oxide characteristics 
have not been known well.

In this study, assuming that solid state-oxidation is fundamental mechanism of IGSCC, oxidation behavior and cracking susceptibility of $\mathrm{Ni}-\mathrm{Cr}$ alloys with different $\mathrm{Cr}$ content under extremely-low oxygen partial pressure have been investigated by oxidation experiments using plate specimens and Reverse U-bend (RUB) specimens in two kinds of gas system under various oxygen potential range.

\section{Experimental details}

\subsection{Materials}

Three kinds of Ni-Cr alloys with different $\mathrm{Cr}$ content (Ni-14Cr, Ni-22Cr, and Ni-30Cr) were made for this study. The alloys were solution heat-treated at $1180{ }^{\circ} \mathrm{C}$ for 30 minutes after homogenizing heat-treatment at $1230{ }^{\circ} \mathrm{C}$ for 10 hours and hot-rolling. Chemical compositions and mechanical properties of the alloys are shown in Tables 1 and 2. Plate specimens and RUB specimens were fabricated from the alloys. Plate specimens of approximately $10 \times 10 \times 2 \mathrm{~mm}$ dimensions were mechanically polished to 2400 grid surface finish using $\mathrm{SiC}$ paper. RUB specimens were polished with 320 grid $\mathrm{SiC}$ paper before bending. All specimens were ultrasonically cleaned in acetone before use for the oxidation experiments.

Table 1 Chemical compositions of Ni-Cr alloys used [wt \%]

\begin{tabular}{|c|c|c|c|c|c|c|c|c|c|}
\hline & $\mathbf{N i}$ & $\mathrm{Cr}$ & $\mathrm{Fe}$ & $M n$ & $\mathbf{M r}$ & $\mathbf{S i}$ & $\mathbf{P}$ & $\mathbf{S}$ & G \\
\hline $\mathrm{NF}-14 \mathrm{Cr}$ & Bal & 13.89 & 0.014 & 0.049 & 0.008 & $<0.001$ & 0.002 & $<0.001$ & 0.006 \\
\hline $\begin{array}{l}\mathrm{N}-22 \mathrm{Cr} \\
\mathrm{Ni}-30 \mathrm{Cr}\end{array}$ & $\begin{array}{l}\text { Bal } \\
\text { Bal }\end{array}$ & $\begin{array}{l}21.87 \\
29.67\end{array}$ & $\begin{array}{l}0.019 \\
0.029\end{array}$ & $\begin{array}{l}0.046 \\
0.044\end{array}$ & $\begin{array}{l}0.003 \\
0.002\end{array}$ & $\begin{array}{l}0.007 \\
0.012\end{array}$ & $\begin{array}{l}0.001 \\
<0.001\end{array}$ & $\begin{array}{l}<0.001 \\
<0.001\end{array}$ & $\begin{array}{l}0.004 \\
0.003\end{array}$ \\
\hline
\end{tabular}

Table 2 Mechanical properties of Ni-Cr alloys used

\begin{tabular}{|c|c|c|c|c|c|c|}
\hline & $\begin{array}{c}0.2 \% \text { proof } \\
\text { stress }\end{array}$ & $\begin{array}{c}\text { tensile } \\
\text { strength }\end{array}$ & Elongation & $\begin{array}{c}\text { Young's } \\
\text { modulus }\end{array}$ & $\begin{array}{c}\text { Poisson's } \\
\text { ratio }\end{array}$ & $\begin{array}{c}\text { Hardness, } \\
\text { HBW }\end{array}$ \\
\cline { 2 - 7 } & $\mathrm{N} / \mathrm{mm}^{2}$ & $\mathrm{~N} / \mathrm{mm}^{2}$ & $\%$ & $\mathrm{GPa}$ & - & - \\
\hline $\mathrm{Ni}-14 \mathrm{Cr}$ & 115 & 458 & 51.0 & 210 & 0.260 & 110.2 \\
\hline $\mathrm{Ni}-22 \mathrm{Cr}$ & 151 & 531 & 63.0 & 209 & 0.274 & 132.4 \\
\hline $\mathrm{Ni}-30 \mathrm{Cr}$ & 208 & 567 & 57.3 & 202 & 0.255 & 113.2 \\
\hline
\end{tabular}

\subsection{Oxidation Experiments}

Oxidation experiments were performed for 750 hours at $400{ }^{\circ} \mathrm{C}$ in two kinds of gas system, one is "inert gas system" which consists of inert gas and trace oxygen, and the other is "dry steam system (hydrogenated superheated steam)" under various oxygen potentials. The reason that the two types of gas systems were adopted for environment of the experiments is to evaluate water molecule effect on characteristics of oxide ${ }^{(7)}$ and cracking susceptibility of Ni-Cr alloys. Figure 1 shows target oxygen partial pressure $\left(\mathrm{P}_{\mathrm{O} 2}\right)$ in the experiments. The target $\mathrm{P}_{\mathrm{O} 2}$ of the experiments was determined based on alloying elements $\left(\mathrm{Ni}, \mathrm{Cr}\right.$ )/oxide equilibrium. Since it is possible that the actual $\mathrm{P}_{\mathrm{O} 2}$ might be different from the target $\mathrm{P}_{\mathrm{O} 2}$, pure metal $(\mathrm{Cu}, \mathrm{Fe}, \mathrm{Ni}$, and $\mathrm{Co})$ specimens were also set with specimens in the test section to evaluate the actual $\mathrm{P}_{\mathrm{O} 2}$ range from the basis of presence or absence of oxide films on the pure metal specimens after the oxidation experiments.

The schematic of test loop of inert gas system is shown in Fig. 2. Though high purity Ar gas $(99.9999 \%)$ was supplied to test loop, it contains much amount of oxygen compared with the target $\mathrm{P}_{\mathrm{O} 2}$ range and impurity of water molecules. First, water molecules were removed using by cold trap, after that amount of oxygen molecules were reduced to the target $\mathrm{P}_{\mathrm{O} 2}$ by oxidation of the pure metal wool in the getter section. The $\mathrm{P}_{\mathrm{O} 2}$ level of testing gas was determined to the dissociation pressure of getter metal (ex. Ti, Fe, Ni, or $\mathrm{Cu}$ ) / 
oxide at any temperature condition.

The schematic of test loop of dry steam system has been shown in Fig. 3. The target $\mathrm{P}_{\mathrm{O} 2}$ was achieved by an adjustment of hydrogen-to-water vapor partial pressure ratio. High-purity water was evaporated at steam generator, and then it was mixed with a predetermined volume of hydrogen gases at the upper stream of the test section.

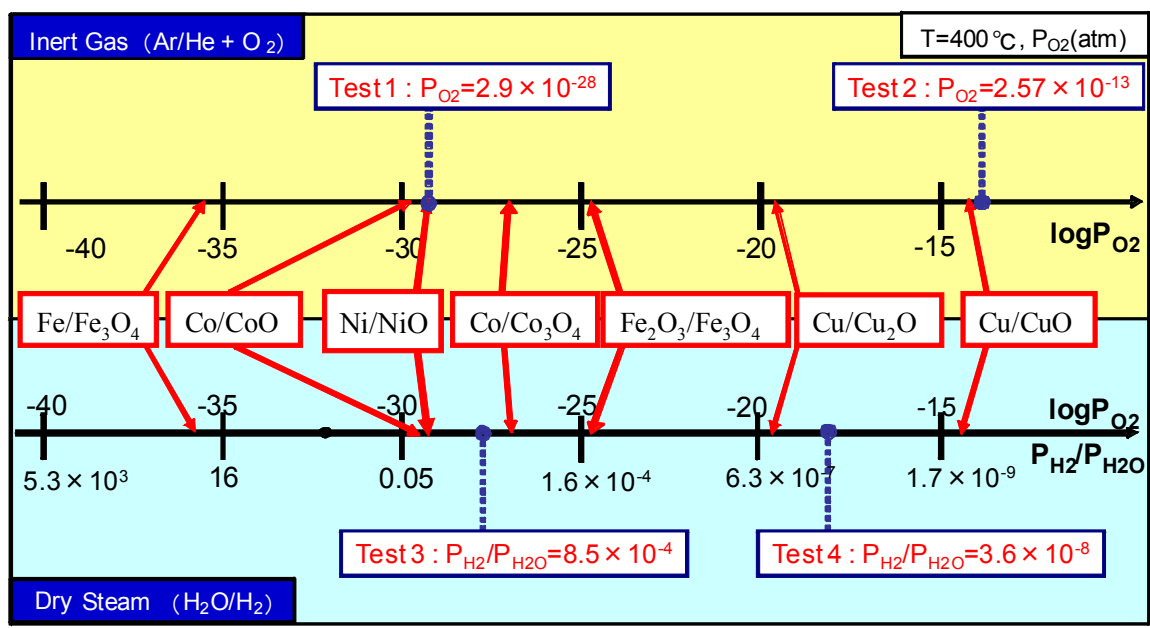

Figure 1 Target potential of oxidation experiments

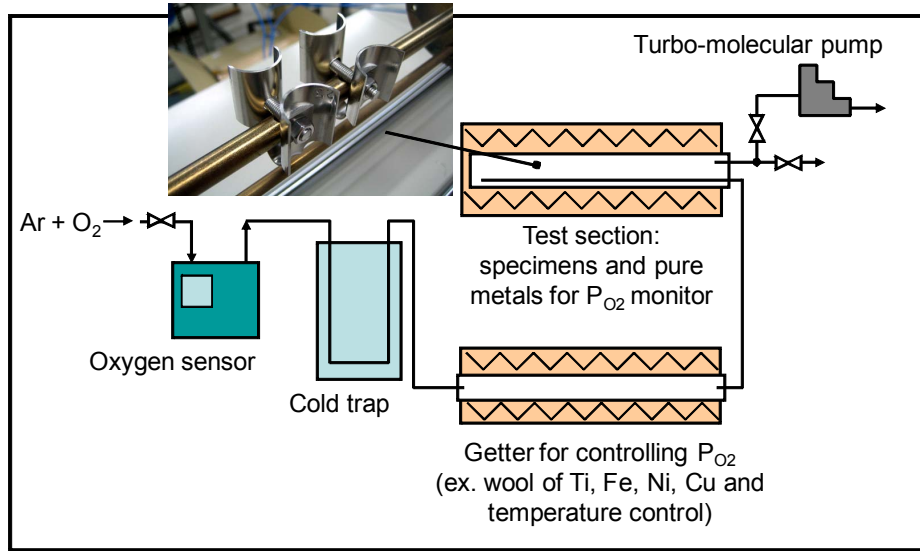

Figure 2 Schematic of test loop: Inert Gas + Trace Oxygen

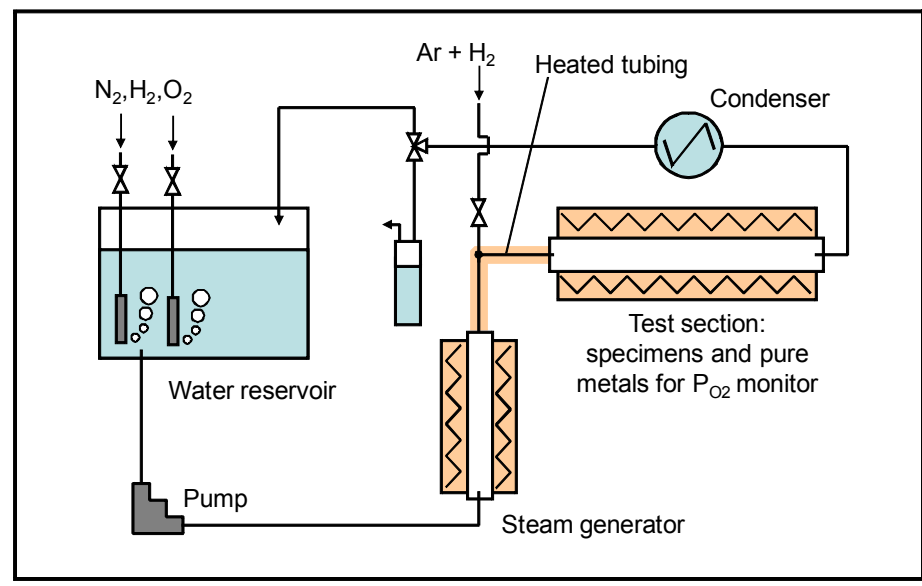

Figure 3 Schematic of test loop: Hydrogenated Superheated Steam 


\section{Results and discussion}

\subsection{Validation result of the actual oxygen potential}

Figure 4 shows target $\mathrm{P}_{\mathrm{O} 2}$ and actual $\mathrm{P}_{\mathrm{O} 2}$ ranges which was determined by presence or absence of oxide films on the pure metal specimens after the oxidation experiments, and it suggests that the actual $\mathrm{P}_{\mathrm{O} 2}$ is lower than target $\mathrm{P}_{\mathrm{O} 2}$ in all the experiments. While there were a certain level of gap between the target $\mathrm{P}_{\mathrm{O} 2}$ and actual $\mathrm{P}_{\mathrm{O} 2}$, the oxidation experiments in extremely-low oxygen partial pressure were achieved in this study.

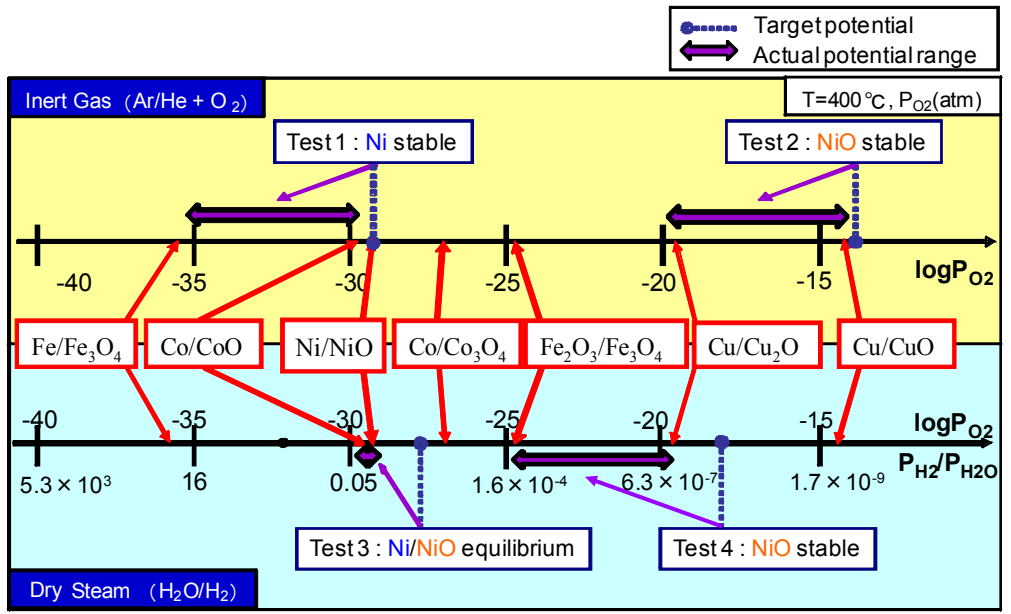

Figure 4 Validation result of the actual oxygen potential

\subsection{Inert gas system (with trace $\mathrm{O}_{2}$, without $\mathrm{H}_{2} \mathrm{O}$ )}

The surface oxide and cracking morphologies of RUB specimen in NiO stable condition $\left(\log \mathrm{P}_{\mathrm{O}_{2}}=-19\right.$ to -15$)$ are shown in Fig. 5. Cracks have been observed in all the specimens, and surface morphology and cracking susceptibility seems to be totally different between the $\mathrm{Ni}-14 \mathrm{Cr}$ and the others. The ragged surface morphology and a number of millimeter-scale IG cracks have been observed in the Ni-14Cr; on the other hand, relatively smooth surface morphology and only one small crack have been observed in the $\mathrm{Ni}-22 \mathrm{Cr}$ and Ni-30Cr, respectively. The difference in cracking susceptibility is considered to be caused by protective oxide film formed or not. It has been also suggested that the threshold level of $\mathrm{Cr}$ content required for the protective oxide film to form in the $\mathrm{P}_{\mathrm{O} 2}$ range locates somewhere in between $14 \mathrm{wt} \%$ and $22 \mathrm{wt} \%$. However, even Ni-30Cr was not immune to IG cracking in the $\mathrm{NiO}$ stable condition.
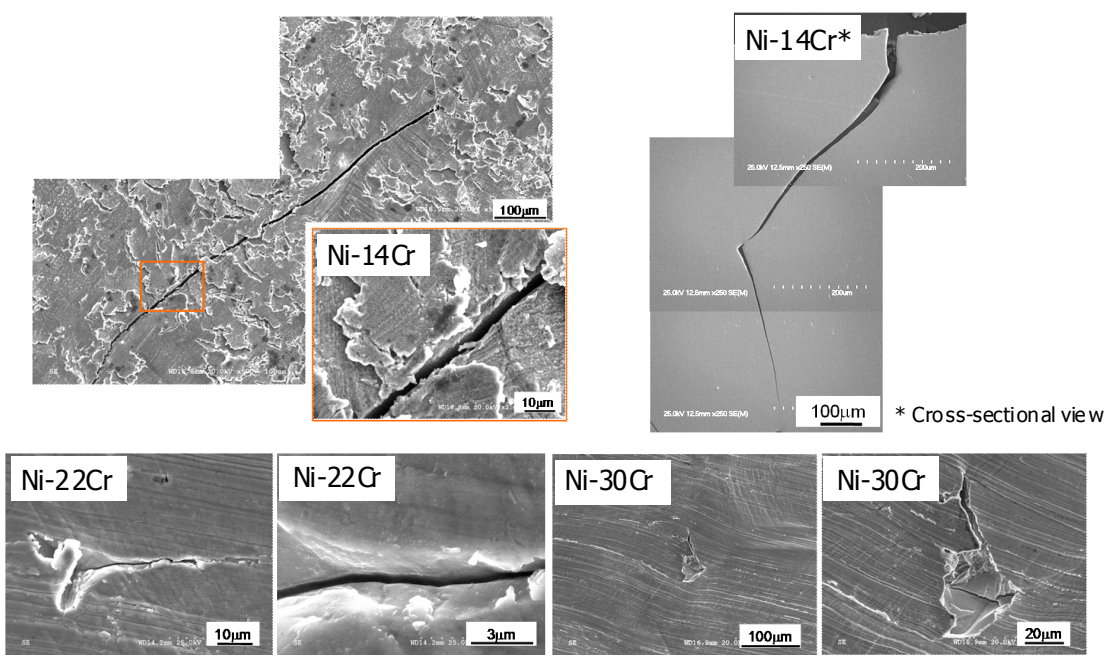

Figure $5 \mathrm{NiO}$ stable-inert gas: appearance and cross-sectional view of RUB specimen 
The surface morphologies of RUB specimen in Ni stable condition $\left(\log \mathrm{P}_{\mathrm{O} 2}=-35\right.$ to -29$)$ are shown in Fig. 6. No crack has been found in all $\mathrm{Ni}-\mathrm{Cr}$ alloys, but the surface morphology of $\mathrm{Ni}-22 \mathrm{Cr}$ seems more ragged compared with that of the others.
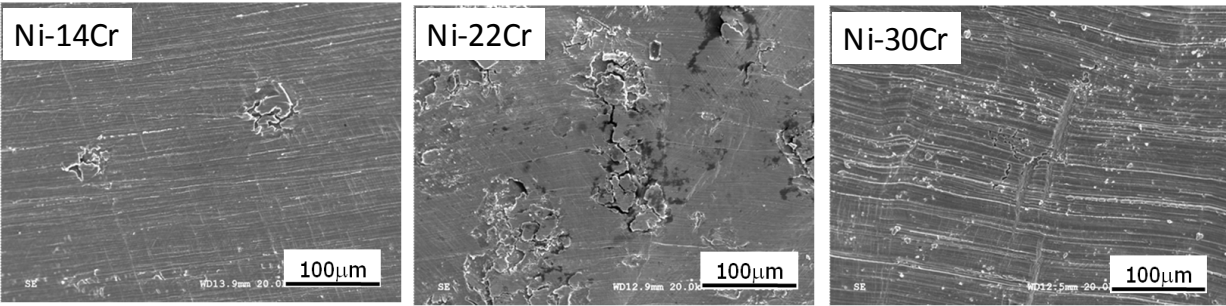

Figure 6 Ni stable-inert gas: appearance of RUB specimen

\subsection{Dry steam system (hydrogenated superheated steam)}

The surface oxide and cracking morphologies of RUB specimen in near $\mathrm{Ni} / \mathrm{NiO}$ equilibrium $\left(\log \mathrm{P}_{\mathrm{O} 2}=-29\right.$ to -28$)$ are shown in Fig. 7. Cracks have been observed in all the specimens tested near $\mathrm{Ni} / \mathrm{NiO}$ equilibrium, and cracking severity was highest for $\mathrm{Ni}-14 \mathrm{Cr}$ and lowest for $\mathrm{Ni}-30 \mathrm{Cr}$ same as in the case in $\mathrm{NiO}$ stable condition-inert gas system. Figure 8 shows the surface morphology of RUB specimen in near $\mathrm{NiO}$ stable condition $\left(\log \mathrm{P}_{\mathrm{O} 2}=\right.$ -25 to -19$)$. Smooth surface and no crack were found in all the specimens at $\mathrm{NiO}$ stable condition.

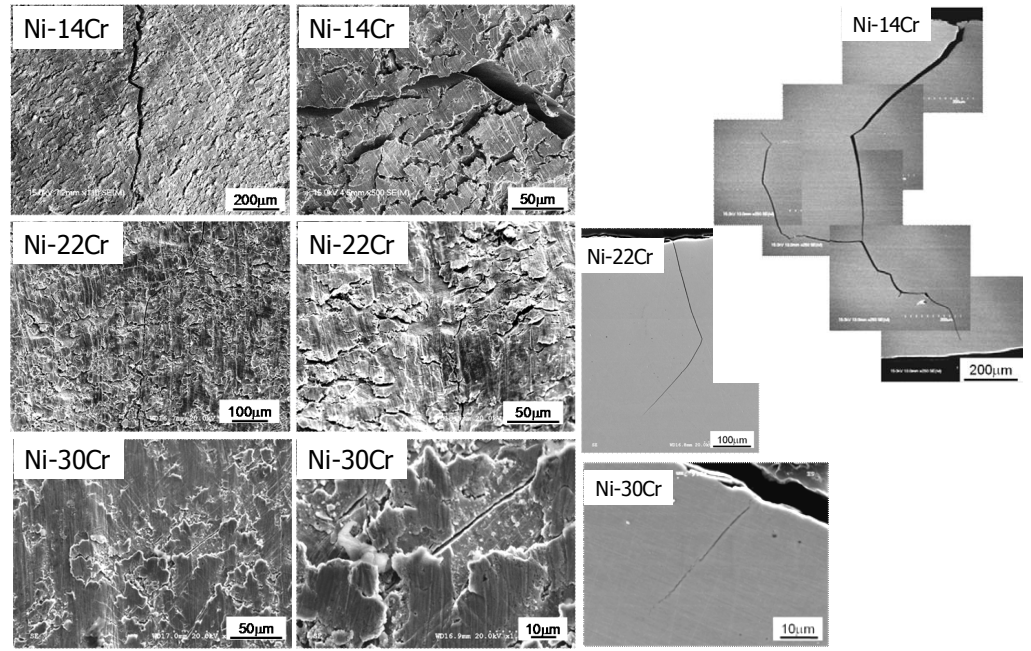

Figure $7 \mathrm{Ni} / \mathrm{NiO}$ equilibrium-dry steam: appearance and cross-sectional view of RUB specimen
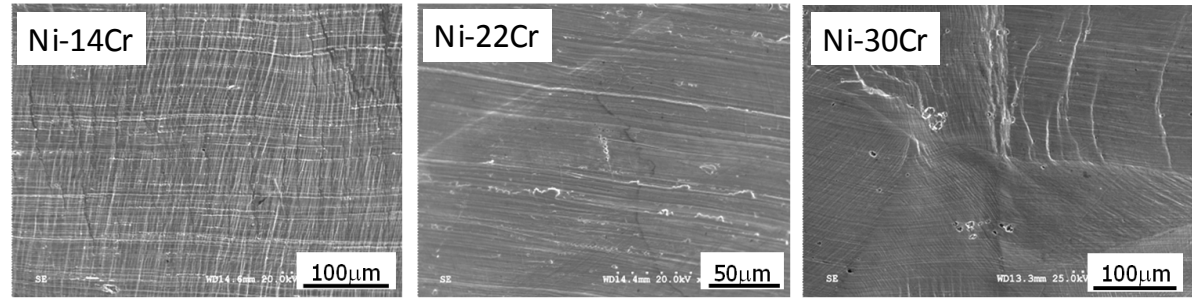

Figure 8 NiO stable-dry steam: appearance of RUB specimen 


\subsection{Summary of cracking susceptibility}

The cracking susceptibility in all the experiments is summarized in Table 3 . It is suggested that potential range for the cracking susceptibility seems to be different between the two environments; near $\mathrm{Ni} / \mathrm{NiO}$ equilibrium in hydrogenated steam, while higher $\mathrm{P}_{\mathrm{O} 2}$ for the inert gas system. Further characterizations focused on the oxide film characteristics are needed to reveal the reason for the cracking susceptibility in the certain potential range described above.

Table 3 Summary of cracking susceptibility

\begin{tabular}{|c|c|c|c|c|}
\hline & \multirow{2}{*}{ Environment } & \multicolumn{3}{|c|}{ Materials } \\
\hline & & $\mathrm{Ni}-14 \mathrm{Cr}$ & $\mathrm{Ni}-22 \mathrm{Cr}$ & $\mathrm{Ni}-30 \mathrm{Cr}$ \\
\hline \multirow{2}{*}{ 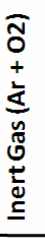 } & $\begin{array}{c}\text { Inert Gas } \\
\text { Ni stable } \\
\left(\log \mathrm{P}_{02}=-35 \sim-29\right)\end{array}$ & No Crack & No Crack & No Crack \\
\hline & $\begin{array}{c}\text { Inert Gas } \\
\mathrm{NiO} \text { stable } \\
\left(\log \mathrm{P}_{\mathrm{O} 2}=-19 \sim-15\right)\end{array}$ & Cracked & $>$ Cracked & $=$ Cracked \\
\hline \multirow{2}{*}{ 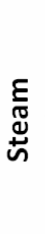 } & $\begin{array}{c}\text { Dry Steam } \\
\mathrm{Ni} / \mathrm{NiO} \text { equilibrium } \\
\left(\log \mathrm{P}_{\mathrm{O} 2}=-29 \sim-28\right)\end{array}$ & Cracked & $>$ Cracked & $>$ Cracked \\
\hline & $\begin{array}{c}\text { Dry Steam } \\
\text { NiO stable } \\
\left(\log \mathrm{P}_{\mathrm{O} 2}=-25 \sim-19\right)\end{array}$ & No Crack & No Crack & No Crack \\
\hline
\end{tabular}

\section{Conclusion}

Oxidation behavior and cracking susceptibility of $\mathrm{Ni}-\mathrm{Cr}$ alloys with different $\mathrm{Cr}$ content under extremely-low oxygen partial pressure have been investigated by oxidation experiments using plate specimens and RUB specimens in two kinds of gas system under various oxygen potential range. The main conclusions can be summarized as follows;

(1) The Ni-Cr alloys have cracked along grain boundary both in inert gas system (with trace $\mathrm{O}_{2}$, without $\mathrm{H}_{2} \mathrm{O}$ ) and in hydrogenated steam.

(2) Potential range for the cracking susceptibility seems to be different between the two environments; near $\mathrm{Ni} / \mathrm{NiO}$ equilibrium in hydrogenated steam, while higher $\mathrm{P}_{\mathrm{O} 2}$ for the inert gas system.

(3) Cracking severity has been highest for $\mathrm{Ni}-14 \mathrm{Cr}$ and lowest for $\mathrm{Ni}-30 \mathrm{Cr}$ both in inert gas and steam; however, even $\mathrm{Ni}-30 \mathrm{Cr}$ has been not immune to IG cracking in steam near $\mathrm{Ni} / \mathrm{NiO}$ equilibrium.

\section{Acknowledgement}

This research work was partly supported by "Innovative and Viable Nuclear Energy Technology (IVNET) Development Project" funded by the Ministry of Economy, Trade and Industry (METI), Japan.

\section{References}

(1) L.E. Thomas and S.M. Bruemmer, High-resolution characterization of intergranular attack and stress corrosion cracking of Alloy 600 in high-temperature primary water, CORROSION, Vol.56, No.6, (2000), pp.572-587

(2) S.M. Bruemmer and L.E. Thomas, Comparison of IGSCC crack-tip characteristics 
produced in BWR oxidizing water and BWR Hydrogen water chemistry conditions, Proceedings of 13th International Conference on Environmental Degradation of Materials in Nuclear Power Systems-Water Reactors, (2007).

(3) B.M. Capell and G.S. Was, Selective internal oxidation as a mechanism for intergranular stress corrosion cracking of Ni-Cr-Fe alloys, Metallurgical and Materials Transactions A, Vol.38A, (2007), pp.1244-1259

(4) G. Economy, R.J. Jacko and F.W. Pement, IGSCC behavior of alloy 600 steam generator tubing in water or steam test above $360{ }^{\circ} \mathrm{C}$, CORROSION, Vol.43, No.12, (1987), pp.727-734

(5) G. Sui, J.M. Titchmarsh, G.B. Heys and J. Congleton, Stress corrosion cracking of alloy 600 and alloy 690 in hydrogen/steam at $380{ }^{\circ} \mathrm{C}$, Corrosion Science, Vol.39, No.3, (1997), pp.565-587

(6) F. Scenini, R.C. Newman, R.A. Cottis, R.J. Jacko, Dependence of PWSCC of alloy 600 on its oxidation behavior, CORROSION 2007, Paper No.07611, (2007)

(7) E. Essuman, G.H. Meier, J. Zurek, M. Hänsel, T. Norby, L, Singheiser, W.J. Quadakkers, Protective and non-protective scale formation of $\mathrm{NiCr}$ alloys in water vapour containing high- and low- $\mathrm{pO}_{2}$ gases, Corrosion Science, Vol.50, (2000), pp. $1753-1760$ 